\title{
THE ROLE OF ICT IN SCALING UP THE IMPACT OF SOCIAL ENTERPRISES
}

\section{RAMON FISAC-GARCIA}

Universidad Politécnica de Madrid

Madrid, Spain

ramon.fisac@upm.es

MANUEL ACEVEDO-RUIZ

Universidad Politécnica de Madrid

Madrid, Spain

manuel@manuelacevedo.net

ANA MORENO-ROMERO

Universidad Politécnica de Madrid

Madrid, Spain

ana.moreno.romero@upm.es

THANE KREINER

Santa Clara University

Santa Clara, California, U.S.A.

tkreiner@scu.edu

Abstract. Information and Communication Technologies (ICT) can help social enterprises and other organizations working on global sustainability issues and in the human development sector in general scale their social impact. The flexibility, dynamism, and ubiquity of ICTs make them powerful 
tools for improving relationships among organizations and their beneficiaries, multiplying the effects of action against many, if not all, aspects of global unsustainability, including poverty and exclusion. The scaling of social impact occurs in two different dimensions. On one hand, ICTs can increase the value proposition of a program or action (depth scaling) in different ways: providing accurate and fast needs recognition, adapting products and services, creating opportunities, building fairer markets, mobilizing actions on environmental and social issues, and creating social capital. On the other hand, ICTs can also increase the number of people reached by the organization (breadth scaling) by accessing new resources, creating synergies and networks, improving organizational efficiency, increasing its visibility, and designing new access channels to beneficiaries. This article analyzes the role of ICT in the depth and breadth scaling of social impact.

\section{INTRODUCTION}

In recent years, the field of environmental action and human development has been searching for tools and methodologies to expand the impact of initiatives that alleviate poverty and protect the environment. Different Information and Communication Technologies (ICTs) - from radio and television to the newest Internet-based smartphones-have constituted a disruptive revolution in the last three decades, radically transforming how we interact with other individuals and organizations. These devices and their applications allow users to find new ways of collaboration, new and sustainable business models, and cost-effective modes of scaling social innovation; however, their effects have not been quantified.

The main objective of this article is to shed some light on the question "How can ICT help organizations, especially social enterprises that pursue initiatives to create a more sustainable world, achieve greater impact?" Our research attempts to systematize existing knowledge and identify key technological factors that can help social enterprises and other organizations committed to social and environmental justice improve their performance. In doing so, we hope to raise awareness of the high potential that ICT has to change lives and make a global impact.

The challenge of global sustainability is complex and involves interconnected issues ranging from environmental degradation to consumption patterns. While ICT can contribute to more sustainable approaches in many ways, this article illustrates how ICT addresses the two important issues of poverty and social exclusion, which are inextricably 
linked to environmental degradation and unsustainable consumption patterns. While the resolution of these pressing problems of humanity is central to global sustainability, they represent only two illustrations of how ICT can contribute to initiatives across the entire range of issues related to global sustainability.

Social enterprises offer a wide array of solutions aimed at solving social problems through a market approach (i.e., the sale of goods and services). This approach helps to ensure the financial sustainability of such enterprises, but it is understood in different ways depending on the geographical and cultural context (e.g., Yunus, 2007; Defourny \& Nyssens, 2008). In this article, we analyze how ICTs can help social enterprises to improve their performance and thus their social impact, and with commensurate returns to global sustainability.

First, we briefly review the conceptual framework of social impact in general and the challenges involved in measuring social impact. Second, we address the issue of scaling social impact over larger populations and/ or geographies. We then explore different beneficial effects that ICT provides to development stakeholders.

\section{SOCIAL IMPACT AND MEASUREMENT}

Because of the complexity of effective human development paradigms, our analysis is wide and general, including actions in both developed and developing countries. Actions to achieve a more sustainable world are, of course, carried out by many different stakeholders, not just social enterprises: NGOs, private companies, governments, aid agencies, etc. To focus our discussion, we will emphasize two of the most critical parts of the global unsustainability problem: poverty and social exclusion. We understand poverty and social exclusion as arising from a complex mosaic of realities caused by a shortage in one or more fundamental aspects of human life: access to water, healthcare, housing, security, financial services, education, etc. (Subirats, 2009). This multidimensional deprivation impedes people from living at the fullest levels of mind and spirit (Chu, 2013).

\section{Defining Social Impact}

According to Mulgan (2010), defining social value is a difficult task because value is "not an objective, fixed, and stable fact, but subjective, malleable, and variable." Most modern economists now agree with Mulgan that in many fields of social action, there is no consensus about what 
the desired outcome should be. A definition of social impact argues "not only about social value, but also about social values" (Mulgan, 2010). In this sense, definitions of social impact found in the literature normally ignore the discussion of what is good and desirable and focus instead on the effects and changes that social value generates.

The Organization for Economic Co-operation and Development (2004) has defined impact as "positive and negative, primary and secondary long-term effects produced by a development intervention, directly or indirectly, intended or unintended." Other authors propose definitions based on the effects caused to individuals (London, 2009), or to a system as a whole (Ashoka, 2010).

In a micro-level approach, Vanclay (2003) defines social impact as "changes to one or more of the following aspects in human lives: 1) people's way of life, 2) their culture, 3) their community, 4) their political systems, 5) their environment, 6) their health and wellbeing, 7) their personal and property rights, and 8) their fears and aspirations." This definition highlights the multidimensional condition of human nature (Yunus, 2007) and makes clear that poverty is not only about not having money but also about living a life that is not at its full potential in different aspects (Duflo, 2009).

Most of the initiatives oriented to fight poverty affect one or more aspects of human life. For example, a program aiming to provide access to the Internet in an isolated rural area through a telecenter can have impact on people's lifestyles and on their community as well as on their individual rights and aspirations.

In a holistic macro-level approach, Ashoka (2010) defines social impact as a systemic change that affects (or has the potential to affect) large numbers of people or industries as a whole. Ashoka divides change systems into five different dimensions: 1) redefining interconnections in market systems, 2) changing public policy and industry norms, 3) transforming the relationship between private and citizen sectors, 4) integrating marginalized populations, and 5) promoting the culture of social entrepreneurship. This approach is summarized by the words of its founder and CEO, Bill Drayton: "social entrepreneurs are not content just to give a fish or teach how to fish. They will not rest until they have revolutionized the fishing industry" (Leviner, Crutchfield, \& Wells, 2007). 


\section{Approaches to Measuring Social Impact}

Social impact is measured by tracking the outputs and outcomes of human development actions and evaluating the resources committed to these tasks. We identify complementary approaches driven by different motivations:

- $\quad$ Social impact assessment is the quest for understanding and explaining external change caused by one organization's actions. In this sense, impact assessment and valuation aims to identify actions that are effective in changing human lives and predict the probable consequences that might result from them. This approach attempts to determine whether the intended impact(s) of the organization is (are) being achieved (Colby, Stone, \& Carttar, 2004), improve the service(s) provided to the beneficiaries (London, 2009), and anticipate negative social impacts that may develop as a result of the social change (Burdge \& Vanclay, 1996).

- $\quad$ Social accounting and auditing is a process for measuring internal performance that informs external communications in two ways. On one hand, social accounting and auditing is used to guarantee that resources are being used in an efficient way. This approach includes the tasks "an organization conducts to make itself accountable to its stakeholders and commit itself to following the audit's recommendations" (Hutchinson \& Molla, 2008). On the other hand, social accounting and auditing can help in capturing new human and economic resources in markets that become more competitive every day. Agents desiring to finance or collaborate in achieving actions committed to positive social ends need metrics to clarify how inputs can contribute to outcomes, as well as to clarify choices and trade-offs (Mulgan, 2010).

While these two approaches are complementary and not mutually exclusive, their focus does differ. Normally, social impact assessment seeks to qualitatively and quantitatively measure impacts on beneficiaries, while social accounting and auditing focuses on the quantitative resources committed by social investors and/or donors. 
Metrics have proliferated over the last 40 years, resulting in hundreds of competing methods for calculating social value (Mulgan, 2010). But even if there is no unique, singularly accepted framework or methodology for impact assessment, there has been progress in recent years toward standardization. These frameworks and methodologies include:

- $\quad$ business process management methodologies like the Balanced Scorecard (Kaplan \& Norton, 1992) and the triple bottom-line (Elkington, 1997),

- $\quad$ qualitative assessment frameworks such as the theory of change (Colby et al., 2004; Weiss, 1998) and the Base of the Pyramid Impact Assessment Framework (London, 2009), and

- $\quad$ quantitative assessment methods and frameworks, including cost-benefit analysis (e.g., Karoly, 2008), Social Return On Investment (Roberts Enterprise Development Fund, 2001), The Best Available Charitable Option (Acumen Fund, 2007), Expected Return (William and Flora Hewlett Foundation, 2008), and the Impact Reporting and Investment Standards (Global Impact Investing Network, 2011).

A major goal for practitioners today is the development of a set of indicators and metrics that make the measurement of social value possible and comparable across different initiatives.

\section{Abstract Challenges of Measuring Social Impact}

Two abstract challenges in social impact measurement and assessment concern the definition of social value and its quantification in comparable units. From the definitions of impact, we notice that the term includes a wide range of aspects in the life of a person, some of them rather abstract or intangible: rights, aspirations, culture, well-being. A consequent question is "Is it possible to measure these elements quantitatively?"

Even if some aspects of social valuation remain beyond current metrics, we should "commit ourselves to the creation of new words and numbers pegged to expressing that which we seek to explain" (Emerson, 2000). While perfect ways do not exist to measure even specific impact (e.g., health outcomes), social entrepreneurs and others can follow some indicators and figures to gain a better understanding of the impact of their actions. 
Another abstract challenge of impact assessment is the multi-causality relation of actions (Austin, Stevenson, \& Wei-Skillern, 2006). In development programs, even when improvements can be measured, it is often difficult to attribute them to specific interventions (Dees, 1998) because they may respond to a combination of various direct and indirect effects.

The social nature of human life (composed of interconnected dimensions), the dynamism of the context (changing conditions over time), and the nature of developmental programs (composed of different actions) make it difficult to isolate the root cause of changes resulting from human and organizational actions. To draw valid conclusions about impact, an unaffected group or set of entities would be necessary to account for what would have happened had the venture never launched (London, 2009).

The issue of multi-causality is being explored by Banerjee and Duflo from the Abdul Latif Jameel Poverty Action Lab at the Massachusetts Institute of Technology. They have been using randomized evaluation, a methodology widely applied in medicine and natural sciences that addresses this challenge. It allows for rigorous evaluation of the impact by decomposing the problem and analyzing each particular element and the relations among elements (Duflo, 2009). However, a challenge in assessing social impact is that "control" groups will likely differ from the "experimental" group based on local contextual factors. There are also ethical considerations in applying the randomized controlled trial paradigm to humans when an intervention exists that is believed to provide better outcomes.

\section{Operational Challenges of Measuring Social Impact}

In addition to these abstract challenges, there are operational and measurement process challenges in impact assessment. Many of these can be addressed or ameliorated by ICT.

Social enterprises and many other human development practitioners often have very limited resources to invest in their attempts to develop conclusions about their social impact. Measurement and assessment is a complex process that needs scientific design of trials and rigorous treatment of data to yield valid, meaningful, and statistically significant conclusions. According to London (2009), organizations working with the socio-economic base of the pyramid usually do not have robust enough systems for accurate assessment. They may also simply evaluate the wrong measures, i.e., ones that do not relate to social impact. These deficits in measurement and assessment are partially caused by the limited resources of these organizations. In this regard, ICT can help 
to create ecosystems that connect different data scientists and thematic experts with practitioners to make the assessment process easier and more effective (Porway, 2011).

A second operational challenge is the difficulty and expense of data collection. Traditionally, the methods that have been used by organizations to monitor human development actions followed a top-down approach: design, execution, and validation are carried out by experts without the participation of beneficiaries. The main problem of this top-down strategy is that it makes the process long and expensive. The diffusion of ICT technologies on a global scale reduces the difficulties associated with collecting data. For example, mobile phone technology is ubiquitous - there are 3.2 billion mobile phone subscriptions in the world (GSM Association, 2013) - and can be used as an inexpensive and reliable way to collect first-hand, unbiased information from and by grassroots beneficiaries.

A third operational challenge is data processing. Accountability and impact assessment can represent a significant resource commitment for human development organizations, especially for the smaller ones. Depending on whether or not an organization's funders allocate sufficient resources for outcomes monitoring, impact measurement can burden the operations of an organization. This workload can be simplified with the use of ICT. Not only does technology help to organize data more quickly and systematically, it can also automate processes for periodic data acquisition. For example, telemedicine applications for elderly care can track patients' key indicators (e.g., blood pressure) by sending information on a periodic basis through devices connected to the Internet.

The validity of data is often time-constrained; in some cases, data collected have short validity (Austin et al., 2006) due to long trials and/ or changing conditions. Trials and assessment projects may take several months or years to be carried out, and it can be difficult or expensive to assure that the data are still valid after long periods. Conditions change, people change, and the organization changes. In this dynamic scenario, the conclusions that arise from such studies may be rendered obsolete from the moment they are initiated. ICTs can help solve these types of problems by enabling real time exchanges or asynchronous but frequent exchanges, establishing bidirectional communication channels that work well in dynamic conditions. In such contexts, data can be tracked, feedback loops are possible, and updating the data is simple. In the words of Gisli Olaffson, Emergency Response Director of NetHope, "data become alive if enhanced by technologies" (Personal interview with Gisli Olaffson, 2013). 


\section{THE ROLE OF ICT IN SCALING IMPACT}

ICTs have great potential for empowering and strengthening sociallyoriented organizations in their quest for impact. Yunus (2007) points out that "the new ICT can allow poor economies to abandon past economic development trends and integrate instead into the world economy much faster than anyone could have supposed." Duncombe (2008) underlines the need for ICTs for inclusive or pro-poor markets, particularly for small and micro-enterprises in value chains, as they are important tools for improving market coordination, efficiency, transparency, and equity.

\section{The Need for Scaling Social Impact}

When organizations or individuals identify a program, model, methodology, or some other action that proves effective in poverty and exclusion alleviation, the next phase is to replicate and scale such on a global basis.

From an entrepreneurial point of view, scaling social benefit ventures means "equipping social benefit entrepreneurs with tools and techniques to effectively accomplish their goals related to serving more of their target beneficiaries" (Koch, Coppock, Guerra, \& Bruno, 2004).

The need for scale derives from the fact that local actions have physical limitations in reaching people in need. Sir Fazle Hasan Abed, founder of BRAC, the Bangladeshi NGO named the largest in the world, says: "If you want to do significant work, you have to be large." Discussing the vision of the twentieth century economist E. F. Schumacher, author of Small is Beautiful, Abed adds: "small may be beautiful, but big is necessary" (Davis, 2013).

In a global world where people suffering the same problems are interconnected, social entrepreneurs and other organizations working in human development are not satisfied with solving just part of the problem, or solving the problem locally. Their aim is to reach a global change, a shift of paradigm that leads to global sustainability.

\section{Different Ways of Scaling Social Impact}

The social impact of a given initiative depends primarily on two variables: how much social value an action generates for each person reached, and how many people are reached by the initiative. When defining beneficiaries and impact, it is essential to account not only for the effects of a given action in present generations, but also how those 
actions will affect future generations. Understanding the social impact of today's interventions on future generations is at an early stage. Consequently, more emphasis and action is required to promote intergenerational equity.

Impact is directly proportional to these two variables: the more valuable the value proposition, the bigger the impact; the wider the collective reach, the bigger the impact. Impact in mathematical terms can be expressed as:

Social Impact $=$ Value Proposition * Number of Beneficiaries

According to this formula, we can differentiate between two ways of scaling social impact (Desa \& Koch, 2010): scope (which we refer to as breadth) scaling and depth scaling:

- Scaling social impact normally refers to breadth scaling, that is, increasing the number of beneficiaries that is reached by the organization or initiative so they can profit from the social value created.

- Social impact can also be increased through depth scaling, which increases the social value proposition already delivered to a given number of beneficiaries by including new features and benefits. This type of scaling is related to being more effective and to expanding the effect of the actions undertaken by organizations.

Table 1 summarizes the main characteristics of these two types of scaling. Next, we explore the effects that ICTs can have which increase each of these types of impact.

\section{The Role of ICT in Depth Scaling}

ICT can help build more efficient and complete products or services that have deeper impact in poverty alleviation. The use of ICT can increase the value proposition in five ways: 1 ) accurate and fast needs recognition, 2) adaptation of products and services, 3) opportunities creation, 4) information disclosure and construction of fairer markets, and 5) inclusion and social capital creation.

\section{Accurate and fast needs recognition}

In today's dynamic world, information changes quickly, and so having current information can be difficult. Information from beneficiaries 
(e.g., needs, preferences, etc.), critical in designing a program or an initiative, is in some cases not attainable by social agents. ICT can thus be a suitable tool for reducing the complexity of data gathering in two ways (Olafsson, 2013):

\begin{tabular}{|c|c|}
\hline \multicolumn{2}{|c|}{ Type of Scaling: Depth Scaling (value proposition) } \\
\hline \multicolumn{2}{|c|}{$\begin{array}{l}\text { Goal: To increase the social value and } \\
\text { effects of an action or program }\end{array}$} \\
\hline Benefit from ICT use & \begin{tabular}{|r|} 
Example \\
\end{tabular} \\
\hline $\begin{array}{l}\text { Accurate and fast } \\
\text { needs recognition }\end{array}$ & $\begin{array}{l}\text { Mobile phone use in emergencies: } \\
\text { Ushahidi (Haiti) }\end{array}$ \\
\hline Opportunities creation & $\begin{array}{c}\text { Online education platforms, social } \\
\text { Business Process Outsourcing: } \\
\text { Samasource (India) }\end{array}$ \\
\hline Products and services adaptation & $\begin{array}{c}\text { Adaptation of WiFi to provide } \\
\text { long-distance telemedicine services: } \\
\text { EHAS (Latin America) }\end{array}$ \\
\hline $\begin{array}{l}\text { Inclusion and } \\
\text { social capital creation }\end{array}$ & $\begin{array}{c}\text { Design of technology-based jobs to } \\
\text { include people in society: } \\
\text { Grameen Telecom (Bangladesh) }\end{array}$ \\
\hline $\begin{array}{l}\text { Information disclosure and fairer } \\
\text { markets construction }\end{array}$ & $\begin{array}{c}\text { Use of mobile phones to promote } \\
\text { market transparency: } \\
\text { M-Farm (Kenya) }\end{array}$ \\
\hline \multicolumn{2}{|c|}{ Type of Scaling: Breadth Scaling (number of beneficiaries) } \\
\hline \multicolumn{2}{|c|}{$\begin{array}{l}\text { Goal: To increase the number of beneficiaries } \\
\text { reached by one action or program }\end{array}$} \\
\hline Benefit from ICT use & Example \\
\hline Access to new resources & $\begin{array}{l}\text { Micro-volunteering, crowdfunding: } \\
\text { KIVA (worldwide) }\end{array}$ \\
\hline $\begin{array}{l}\text { Synergies and } \\
\text { networks construction }\end{array}$ & $\begin{array}{l}\text { Network of social entrepreneurs, } \\
\text { volunteers, mentors, and } \\
\text { stakeholders: Ashoka (worldwide) }\end{array}$ \\
\hline Organizational efficiency & $\begin{array}{l}\text { Alliances, incubators, clusters: } \\
\text { NetHope (worldwide) }\end{array}$ \\
\hline Improved visibility & $\begin{array}{l}\text { Information disclosure for } \\
\text { transparency or advocacy: } \\
\text { Video Volunteers (India) }\end{array}$ \\
\hline $\begin{array}{l}\text { New access channels to } \\
\text { beneficiaries }\end{array}$ & $\begin{array}{l}\text { Access to services through mobile } \\
\text { phones: M-Pesa (Kenya) }\end{array}$ \\
\hline
\end{tabular}

Table 1. The Role of ICT in Scaling Social Impact 
- $\quad$ recognize needs faster and therefore provide a quick response (sometimes almost in real-time) to some problems, and

- $\quad$ understand trends more accurately by gathering large amounts of data ("Big Data"). Big Data can be used in a prospective way to forecast and prevent negative effects, and also in a retrospective way to better understand how to tackle recurrent problems.

For example, Ushahidi is a platform developed in Kenya that crowdsources information from citizens using multiple channels based on ICT, including SMS, email, Twitter, and the Web. This organization helped map violent outbursts in Kenya and Palestine and track the victims of the earthquake in Haiti. In the context of emergency response, real-time and accurate information provided by citizens' mobile telephones can be crucial in allocating resources and offering quick, effective actions.

\section{Adaptation of products and services}

Adapting products and services to the needs of people at the base of the pyramid is one of the key success factors in all human development actions. In this sense, ICT can help adapt products and services by turning physical features into digital ones. This change normally yields a more affordable product due to a reduction in the use of inefficient infrastructure or distribution channels and in the cost of manufacturing and distribution. The array of possibilities that ICT offers in this sense is enormous.

For example, organizations that deliver health services in rural areas can adapt their services to the isolation and lack of infrastructure. Enlace Hispano Americano de Salud (EHAS) is a Spanish-based organization that provides health assistance to the rural areas of five Latin-American countries. This organization makes data transmission possible between health centers in the same region by adapting wireless networks. Instead of using satellite signals which are high cost and low bandwidth, EHAS adapts WiFi technologies (normally used for short-distance) for long-distance and inexpensive communication that increases efficacy and efficiency, and thereby enables provision of better services to communities (Martínez, 2004).

\section{Opportunities creation}

Many economic opportunities in the $21^{\text {st }}$ century are based on access to information, knowledge, and education. ICTs are used to gather, disseminate, exchange, process, store, and access information and 
knowledge, which are essential resources for women and men to live satisfactory lives. The integration of ICTs in human activities is thus consistent with the appearance of the Network Society (Castells, 1998).

Recent years have seen the proliferation of education programs based on different technologies that are changing patterns of education (e.g., Coursera, Udacity, Khan University, and different open coursewares such as MIT Open Courseware). These new solutions provide people all over the world with a wider array of choices. Access to education is not only provided through computers but, as the example of Lifeline in subSaharan Africa shows, also through the use of solar and wind-up radios and MP3 players.

New opportunities can also be created through the adaptation of ICT-based jobs to the base of the pyramid (Heeks, 2010). The emergence of social Business Process Outsourcing (BPO) is an excellent example. Easy tasks and packages of work are outsourced to low-skill workers to provide them a source of income. Samasource, a San Francisco-based social enterprise that connects women and youth living in poverty to dignified work via the Internet, has already paid more than \$2.9 million in wages to more than 3,500 workers (www.samasource.org). Some authors (e.g., Seeth, 2013) have identified the social BPO trend as a "driver of GDP growth and large-scale job creation for developing countries." While GDP growth is an imperfect measure of social impact, dignified work of the sort Samasource catalyzes fuels economic growth.

\section{Information disclosure and fairer markets construction}

Ashoka has identified patterns of changes that leading social entrepreneurs set out to achieve: changes in market systems, cultural and social norms, and public policies and industry norms. ICT can help effect all of these changes.

Mobile technologies can facilitate changes in the flows of market information, access to goods and services, and value chains. For example, M-Farm, a Kenyan organization, has developed a mobile phone platform for Kenyan farmers to get information pertaining to the retail prices of their products, buy their farm inputs directly from manufacturers at favorable prices, and find buyers for their produce. This transparency tool is changing the Kenyan marketplace to a fairer one, enabling more of the economic value of agriculture to accrue to smallholder farmers who comprise half of the jobs in Africa. 
Cultural and social norms, as well as citizen awareness about social entrepreneurship, is spread through viral ICTs: social media, blogs, videos, etc. Different institutions, including foundations, universities, NGOs, and multilateral bodies, are creating momentum in the field of social entrepreneurship by spreading the concept throughout the world and promoting social action.

Changes in public policy and industry norms are more easily promoted with ICT. Social organizations not only have a local effect-they can often achieve national or global level impact. For example, Avaaz (www.avaaz.org) is a global organization that empowers millions of people to take action on different issues, from corruption and poverty to conflict and climate change, through online campaigns. It has more than 20 million members worldwide and has taken more than 117 million social justice actions since 2007.

\section{Inclusion and social capital creation}

The development of communication options has enabled the involvement of more people in collaborative actions than was previously possible. The interaction of beneficiaries with other agents generates social cohesion and social capital, defined as "features of social organization such as networks, norms, and social trust that facilitate coordination and cooperation for mutual benefit" (Putnam, 1995).

Community participation through the use of technologies generates inclusion for the disadvantaged and can also generate ownership of programs by communities, making them more effective and more likely to last over time. ICT provides access to precious resources, including local knowledge about the market, cultural traditions, and other contextual factors that influence adoption of products and services tailored to the poor.

Grameen Telecom is an example of the improvement of social cohesion among the local community. This initiative, launched by Grameen Bank, aimed to provide rural poor in Bangladesh with access to mobile phone communication. A group of "phone ladies" - largely illiterate, excluded, and elderly women from these communities-sells airtime to other villagers, making possible their acceptance in the community, recognizing their role as drivers of economic activity, and building an income generating activity for themselves. 


\section{The Role of ICT in Breadth Scaling}

A traditional paradigm in poverty alleviation and in many other social and environmental initiatives consists of piloting a prototype product or service for a limited period of time and measuring benefits for a small community or cohort. If the initiative shows efficacy and impact, it can be scaled to reach more people in the same target community or in other regions where the same social problem exists. For example, the Naandi Foundation, a nonprofit organization that provides purified drinkable water in rural India, increased its impact through a breadth scaling approach (Desa \& Koch, 2010). The program started with one water purification plant in 2006, and after mastering the solution to one specific need (safe-water availability), the solution was replicated in as many geographical areas as possible. In the period from 2006 to 2009, Naandi built 1,000 plants serving 4 million people.

ICT is a powerful tool for growing the size of these human development initiatives in two directions: providing the outputs and effects to more beneficiaries, and capturing more inputs or resources to make the organization larger.

But ICT can improve an organization's performance independent of its growth. According to Koch et al. (2004), scaling also involves building organizational capacity and the development of business models aimed at sustaining growth. ICT normally implies more efficient management through better communication and organization. This efficiency gain results in the organization's ability to reach more people for a given volume of resources; in other words, ICT creates leverage.

We identify five benefits derived from the use of ICT in breadth impact scaling: 1) access to new resources, 2) synergies and networks creation, 3) organizational efficiency, 4) improved visibility, and 5) new access channels.

\section{Access to new resources}

One challenge that most social impact initiatives (especially nonprofits) face, regardless of size, is the effective capture of new resources for the organization, including voluntary work and economic funds. The crowdsourcing movement, based on the collection of funds through a large group of individuals, can mean significant scale and transformation. In words of Edward G. Happ, founder of NetHope, "if I can spend 
8 hours less to have one hour of impact in the world, that is a huge gain ... and technology is what delivers that type of gain" (NetHope, 2011).

Two examples of the use of ICT to facilitate voluntary work are the Spanish "Microvoluntarios" project started by the Bip Bip Foundation (www.fundacionbipbip.org) and the UK-based platform Help from Home (www.helpfromhome.org). Both initiatives promote micro-volunteer work online to help organizations fight exclusion and poverty. Individuals contribute to a cause by investing their free time to help others with tasks ranging from 30 to 120 minutes. These platforms make possible expertise outsourcing from different fields which helps the daily work of nonprofit organizations in tasks such as proofreading, translation of texts, e-mentoring small entrepreneurs, or, for example, data collection for a project aimed at recording tree populations in a region.

In fundraising efforts, ICT is enabling the crowdfunding movement to create significant impact. Kiva is a non-profit organization that connects entrepreneurs in developing countries with individuals around the globe who lend them small amounts of money (typically from \$25-\$50). The combination of several of these small loans provides the funding for one so called microcredit, typically ranging in the hundreds of dollars, which is received by the borrower and provides her/him with opportunities for income generation. Kiva has revolutionized the micro-finance industry by creating a community of more than 700,000 lenders that have disbursed more than $\$ 300$ million since its founding in 2005 .

\section{Synergies and networks creation}

Since networks are the quintessential organizational structures in the Information Era (Castells, 1998), ICT facilitates information sharing, making coordination easier and effective communication possible.

These benefits have an impact on the performance of individual organizations and also on the performance of the entire social impact sector. ICT helps to create collaborative ecosystems-for example, facilitating and coordinating a network of sustainable relationships, in different spatial and time zones, with different stakeholders: donors and lenders, enterprises, NGOs, governments, technology companies, etc.

One example of networked collaboration is Ashoka Foundation (www.ashoka.org). The support they offer to social entrepreneurs is based upon a worldwide network of fellows (award winning social entrepreneurs), strategic partners (enterprises), experts, and volunteers. In a recent survey, $56 \%$ of the social entrepreneurs interviewed said that Ashoka's 
network was a critical tool for helping them see their work from a new perspective, and 49\% said Ashoka was vital to increasing their impact (Acharya, 2012). In a similar fashion, Hutchinson \& Molla (2008) state that "the most common way ICT helped improve operations of social enterprises was through enabling external communications with clients and customers."

\section{Organizational efficiency}

The incorporation of suitable ICT platforms can help socially-oriented organizations improve their internal performance. First, ICT improves communications with stakeholders such as beneficiaries, clients, and suppliers, enabling higher quality performance at a lower cost. Second, ICT reduces operational costs inside the organization by making labor-intensive activities almost free through the use of appropriate technologies (for example, through the use of digital platforms for grant creation). Third, ICT makes possible the management of a huge amount of small transactions that, without ICT, would simply be cost-prohibitive or impossible given the severe resource constraints of many social impact organizations.

According to Bradach (2010), the main challenge of social innovation is "how to get $100 x$ the impact with only a $2 x$ change in the size of organization." ICT can help create leverage to scale an organization's impact without scaling its size.

One example of organizational efficiency provided by ICT is NetHope (www.nethope.org), a consortium of 38 global NGOs (called members), major technology companies, foundations, and individuals to promote members' better use of technology and the improvement of their performance. NetHope itself uses technologies to make communication among actors possible and valuable: NGOs can reach several members of the consortium at once, saving time and resources.

\section{Improved visibility}

ICTs are inexpensive and effective tools for offering reliable information to multiple stakeholders: employees, donors, and society in general. The goals of information disclosure can be understood from different perspectives. Transparency and openness about how socially-oriented organizations invest funds generates trust that can attract new capital investment and collaborators. ICT also provides low-cost, high quality visibility and advocacy. Some causes quickly acquire international awareness thanks to ICT. The importance of social media and the viral effects of messages through Web 2.0 tools make possible broad dissemination of 
initiatives and messages that can rapidly reach an unexpected scale. The propagation of the "Arab Spring" through social media (e.g., Facebook, Twitter, etc.) is a good example.

In this sense, ICT can be a loudspeaker that enables organizations to connect better with donors/funders and to communicate their messages more clearly. Social media provides a tool for telling human stories that help connect people to social impact initiatives.

\section{New access channels to beneficiaries}

Lack of access to credit, basic services, healthcare, and information are some of the main causes of exclusion and persistent poverty in the developing world. In some cases, the lack of a physical channel precludes provision of the goods and services that would alleviate some exclusion and poverty problems. Access is sometimes difficult and expensive, particularly in rural areas. ICT provides a bi-directional channel:

- $\quad$ Access to markets for people living in isolated areas. For example, smallholder farmers in rural areas in developing countries can communicate with larger organizations to arrange economic transactions. An example of this would be the Alternative Trading Network, which uses mobile phones to coordinate the supply and delivery of goods in rural Nigeria.

- Access to isolated communities for enterprises that provide goods and services. The mobile telephone has allowed the development of micropayments and microcredit in parts of Africa where no physical channel exists. M-Pesa is a service offered by Safaricom and Vodafone in different developing countries that allows users to make payments, transfers, and deposits through mobile phones. This is an innovative channel for providing financing services and business opportunities to the unbanked in those countries.

\section{CONCLUSIONS}

Social enterprises and other actors from public, private, and civil sectors are working on many ways to alleviate poverty, reduce social exclusion, and grapple with other problems of global unsustainability as they seek to meet the world's most pressing needs. 
A wide array of ICTs-telephones, computers, radio, TV, sensors, social media-can be used as tools to increase the impact of all the agents working in these problems. This article demonstrates how efforts to scale social impact have an ally in ICT, and offers some examples in the human development sector.

First, even though impact assessment today is imperfect and challenges exist, ICT can help to overcome these issues in multiple ways:

- The collaborative nature of ICT expands the limited resources of socially-oriented organizations by connecting them to experts and making the heavy workload of data processing easier.

- Since ICT is embedded in all aspects of human life, it provides tools for assessing multiple dimensions of poverty and other global unsustainability issues.

- The dynamism of ICT can keep data current and reduce the time required to assess processes.

- $\quad$ The wide reach of ICT ("Big Data") can reveal trends and help prevent situations before they become problematic.

Second, ICT can help scale social impact directly. Performance improvement can be realized in two dimensions: the social value of a program's impact (depth scaling), and the number of people reached by the organization (breadth scaling). Figure 1 shows these roles of ICT in scaling social impact.

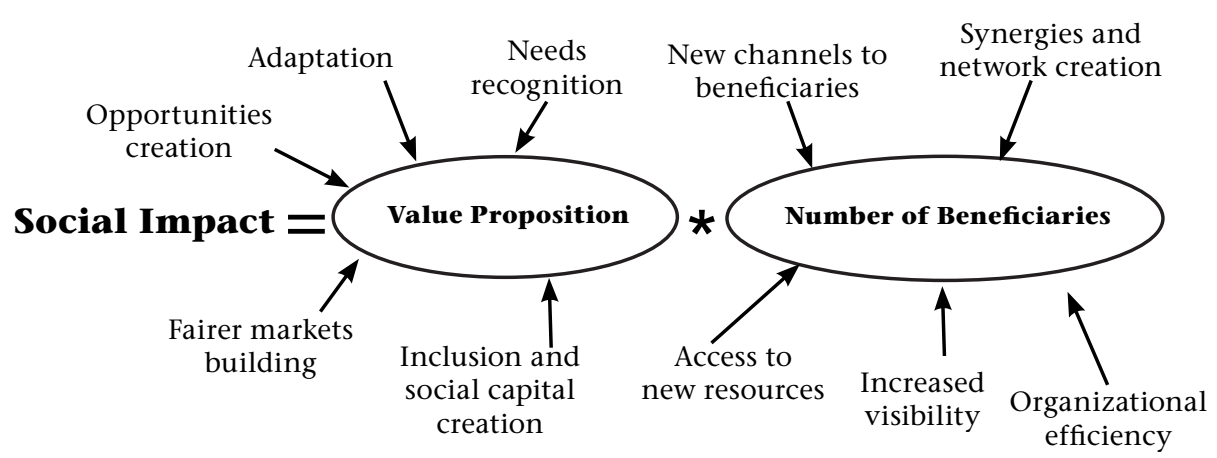

Figure 1: The role of ICT in scaling up social impact) 
On one hand, ICTs can increase the value proposition of a program or action in different ways: providing accurate and fast needs recognition, adapting products and services, creating opportunities, building fairer markets through information disclosure, and creating social capital.

On the other hand, ICT can improve the growth and the reach of an organization in five ways: accessing new resources, creating synergies and networks, improving the organization's efficiency, increasing its visibility, and designing new access channels to beneficiaries.

ICT plays an important role in the quest for better and more effective solutions, but we should be cautious not to overstate the role of ICT in social and environmental initiatives. ICT is neither an unnecessary luxury nor the solution to every problem, but it is a set of tools that opens new possibilities for action and impact.

These tools are not one-size-fits-all solutions. They need to be adapted to the social objectives of each organization and to the local contexts in which these organizations operate. Although common frameworks for thinking about social value are useful, practitioners must adapt these frameworks to the organization and to the desired impacts being sought and assessed.

Future research on the integration of ICT in scaling impact should take into account organizational elements of technology deploymenttechnologies themselves are developing at a fast pace and they present a wide range of possibilities for improving human lives. In our opinion, the biggest challenge today in technological projects facing human development and other issues lies in refining the procedures to make these tools useful for human purposes: applying ICT meaningfully to different social problems, building the capacity to use ICT among the final users, and defining social structures and arrangements capable of effective and efficient uses for these technologies.

\section{REFERENCES}

Acharya, K. 2012. What is the value of a network? Forbes, November 20th, http:// www.forbes.com/sites/ashoka/2012/11/20/what-is-the-value-of-a-network/ (accessed March 21, 2013).

Acumen Fund. 2007. The best available charitable options. Acumen Fund Concepts Series, January 2007, http://www.acumenfund.org/uploads/assets/ documents/BACO\%20Concept\%20Paper\%20final_B1cNOVEM.pdf (accessed March 21, 2013). 
Ashoka. 2010. Ashoka fellows changing systems. Global Study 2009, http://sfs. ashoka.org/sites/sfs/files/2010\%20Ashoka\%20Impact\%20Study.pdf (accessed March 21, 2013).

Austin, J., Stevenson, H., \& Wei-Skillern, J. 2006. Social and commercial entrepreneurship: Same, different, or both? Entrepreneurship Theory and Practice, 30(1): 1-22.

Bradach, J. 2010. Scaling impact. Stanford Social Innovation Review, Summer: 27-28.

Burdge, R.J., \& Vanclay, F. 1996. Social impact assessment: A contribution to the state of the art series. Impact Assessment, 14(1): 59-86.

Castells, M. 1998. La era de la información: Economía sociedad y cultura: La sociedad red (vol. 1). Madrid: Alianza Editorial.

Chu, M. 2013. Private sector and public responsibilities: The role of profit in scaling social impact. Scaling Social Impact Webinar Series (Harvard Business School), January 17, http://blogs.hbr.org/events/2013/02/what-is-the-role-ofprofit-in.html (accessed March 21, 2013).

Colby, S., Stone, N., \& Carttar, P. 2004. Zeroing in on impact in an era of declining resources, nonprofits need to clarify their intended impact. Stanford Social Innovation Review, Fall: 24-33.

Davis, S. 2013. Scaling up without losing your edge. Harvard Business Review Network blog, posted January 18, http://blogs.hbr.org/cs/2013/01/for_social_ enterprises_size_ma.html (accessed January 27, 2013).

Dees, G. 1998. The meaning of social entrepreneurship. Unpublished working paper, Center for the Advancement of Social Entrepreneurship, Duke University, Durham, NC.

Defourny, J., \& Nyssens, M. 2008. Social enterprise in Europe: Recent trends and developments. EMES European Research Network working paper, Brussels.

Desa, G., \& Koch, J. 2010. Scaling social enterprise: A comparative study of Naandi and Drishtee in rural India. Paper presented to the NYU Stern Conference on Social Entrepreneurship, New York.

Duflo, E. 2009. Ending poverty. Poptech.org, October 2009: http://poptech.org/ popcasts/esther_duflo_ending_poverty (accessed March 21, 2013).

Duncombe, R. 2008. ICT, markets and development. In ict Development Associates Ltd (Eds.), Building communications opportunities: Impact assessment study (Report to the Building Communications Opportunities Consortium): $53-74$.

Elkington, J. 1997. Cannibals with forks: The triple bottom line of 21 st century business. Oxford: Capstone.

Emerson, J. 2000. The nature of returns: A social capital markets inquiry into elements of investment and the bended value proposition. Social Enterprise Series Working paper no. 17, Harvard Business School, Cambridge, MA.

Global Impact Investing Network. 2011. Impact reporting and investment standards overview, http://ww w.siaassociation.org/wp-content/ uploads/2012/05/IRIS-Overview-2010.pdf (accessed March 21, 2013). 
GSM Association. 2013. The mobile economy 2013 report, http://www.atkearney. com/documents/10192/760890/The_Mobile_Economy_2013.pdf/6ac117705a26-4fef-80bd-870ab83222f0 (accessed March 21, 2013).

Heeks, R. 2010. Development 2.0: The IT-enabled transformation of international development. Communications of the ACM, 53(4): 22-24.

Hutchinson, K., \& Molla, A. 2008. Mapping the dynamics of social enterprises and ICTD in Cambodia. Paper presented to the Information and Communication Technologies for Development Conference, Doha, Qatar.

Kaplan, R., \& Norton, D. 1992. The balanced scorecard-measures that drive performance. Harvard Business Review, 70(1): 71-79.

Karoly, L. 2008. Valuing benefits in benefit-cost studies of social programs. RAND, http://www.rand.org/pubs/technical_reports/TR643.html (accessed March 21, 2013).

Koch, J., Coppock, K., Guerra, P., \& Bruno, V. 2004. The Global Social Benefit Incubator: Toward a new pedagogy for "scaling" in social benefit entrepreneurship. Nexus STS, Fall: 44-50.

Leviner, N., Crutchfield, L.R., \& Wells, D. 2007. Understanding the impact of social entrepreneurs: Ashoka's answer to the challenge of measuring effectiveness. In R. Mosher-Williams (Ed.), Research on social entrepreneurship: Understanding and contributing to an emerging field, vol. 1(3): 89-103. Indianapolis, IN: ARNOVA Ocasional Paper Series.

London, T. 2009. Making better investments at the base of the pyramid. Harvard Business Review, 87(5): 106-113.

Martínez, A. 2004. Comunicaciones para la salud en países en desarrollo: ¿lujo o necesidad? In Ingenieria sin Fronteras (Ed.), Cuadernos internacionales de tecnología para el desarrollo humano: De la Información y la Comunicación, vol. 2: 1-12. Madrid: Ingeniería sin Fronteras.

Mulgan, G. 2010. Measuring social value. Stanford Social Innovation Review, Summer: $38-43$.

NetHope, 2011. NetHope's anniversary with Edward G. Happ (NetHope video), http://nethope.org/media/videos/\#prettyPhoto-409/0/ (accessed March 21, 2013).

Olafsson, G. 2013. Open data and impact measures. Dealing with Disasters, February 4, http://blog.disasterexpert.org (accessed March 21, 2013).

Organization for Economic Co-operation and Development. 2004. Glossary of key terms in evaluation and results based management, http://www.oecd. org/dac/evaluation/18074294.pdf (accessed March 21, 2013).

Personal interview with Gisli Olaffson. 2013. February 27.

Porway, J. 2011. Data without borders. PopTech.org. http://poptech.org/popcasts/ jake_porway_data_without_borders (accessed March 21, 2013).

Putnam, R. 1995. Bowling alone: America's declining social capital. Journal of Democracy, 6(1): 65-78.

Roberts Enterprise Development Fund. 2001. Social return on investment methodology. 
Seeth, S. 2013. BPO for the BOP (Part 1). Next Billion. http://www.nextbillion.net (accessed March 21, 2013).

Subirats, J. 2009. Pobreza y exclusión social. Un análisis de la realidad española y europea. Colección Estudios Sociales numero 16. Barcelona: La Caixa Foundation.

Vanclay, F. 2003. International principles for social impact assessment. Impact Assessment and Project Appraisal, 21(1): 5-12.

Weiss, C. 1998. Evaluation: Methods for studying programs and policies (2nd ed.). Englewood Cliffs, NJ: Prentice-Hall.

William and Flora Hewlett Foundation. 2008. Making every dollar count: How expected return can transform philanthropy, http://www.hewlett.org/ uploads/files/Making_Every_Dollar_Count.pdf (accessed April 23, 2013).

Yunus, M. 2007. Creating a world without poverty: Social business and the future of capitalism. New York: PublicAffairs. 